\title{
PEMBENTUKAN UMKM MELALUI PROGRAM HIBAH PHP2D KEMDIKBUD SEBAGAI RECOVERY DAMPAK COVID-19 DI DESA GILANGHARJO
}

\author{
${ }^{1 *}$ Riswanda Himawan, ${ }^{2}$ Riefda Arya Kelana, ${ }^{3}$ Tika Afrilia, ${ }^{4}$ Agelia Sari \\ Universitas Ahmad Dahlan, Yogyakarta, Indonesia. \\ Email : 1 riswanda1700003043@webmail.uad.ac.id
}

Manuskrip: Okt-2020; Ditinjau: Nov -2020; Diterima: Des -2020; Online: Jan-2021; Diterbitkan: Jan-2021

\begin{abstract}
ABSTRAK
Pandemi covid-19 menyebabkan berbagai macam dampak yang dialami langsung oleh masyarakat. Salah satu dampak tersebut adalah kesulitan di bidang ekonomi. Kesulitan ekonomi terjadi karena hampir seluruh kegiatan masyarakat dilakukan di rumah saja termasuk perdagangan kuliner berbasis kearifan lokal. Selaras dengan pernyataan tersebut maka perlu adanya solusi agar masalah-masalah ekonomi tersebut dapat diatasi. Salah satunya dengan cara pembentukan UMKM. Pembentukan UMKM dilakukan untuk memudahkan masyarakat dalam menjual dagangan dalam hal ini kuliner berbasis kearifan lokal. Hal ini dilakukan agar masyarakat dapat terarah dan terpusat dalam menjual dagangan yang biasa mereka jual. Sehingga mereka akan lebih mudah memasarkan dagangannya secara terstruktur, bersama dan terorganisir di masa pandemi seperti yang terjadi saat ini. Metode yang dilakukan dalam kegiatann ini adalah; (1) Sosialisasi, (2) Pelatihan strategi pemasaran, (3) Pembentukan UMKM, (4) Pemasaran. Kegiatan ini diharapkan mampu menjadi refrensi dan solusi bagi masyarakat untuk membangkitkan ekonomi mereka di masa pandemi.
\end{abstract}

\section{Kata Kunci : Pembentukan; UMKM; Desa Gilangharjo; Pandemi; Covid-19}

\section{PENDAHULUAN}

Desa Gilangharjo merupakan salah satu desa yang terletak di kecamatan Pandak, Kabupaten Bantul, Provinsi Daerah Istimewa Yogyakarta. Desa Gilangharjo telah dinobatkan sebagai desa budaya oleh pemerintah kabupaten Bantul (Gilangharjo, 2020) sebagai desa budaya, maka tak heran lagi jika banyak potensi masyarakat yang mengembangkan kearifan lokal. Seperti halnya batik khas Bantul, alat-alat kesenian tradisional, hingga kuliner. Dari sekian banyak potensi masyarakat tersebut, hal yang lebih sering dan lebih banyak dilakukan oleh masyarakat adalah mengembangkan kuliner berbasis kearifan lokal.

Seperti menjual kripik gayam, bakmi Jawa, kue-kue tradisional, aneka kripik yang berasal dari tumbuhan yang tumbuh di desa Gilangharjo, dan sebagainya. Maka dari itu, dengan adanya berbagai macam potensi tersebut membuat banyak wisatawan turut hadir untuk berwisata sambil belajar di desa 
Gilangharjo. Namun, saat ini berbagai macam potensi masyarakat tersebut terhambat karena datangnya pandemi Covid-19.

Pandemi COVID-19 adalah bencana kesehatan yang pertama di dunia. Banyak negara memutuskan untuk menutup aktivitas masyarakat yang dilakukan secara langsung di luar rumah.. Perserikatan Bangsa-Bangsa (PBB) menjadi gusar dengan adanya fakta tersebut. Organisasi Internasional yang berada di New York, AS, itu menangkap bahwa pendidikan dan ekonomi menjadi salah satu sektor yang begitu terdampak oleh virus corona. (Purwanto et al., 2020) Pandemi Covid-19 menyebabkan krisis ekonomi, yang secara langsung dialami oleh masyarakat khususnya dalam hal ini adalah masyarakat desa Gilangharjo. Hal ini dibuktikan dengan menurunya angka produksi para pelaku usaha yang ada di desa Gilangharjo, mereka merasa kesulitan untuk memasarkan dagangan yang telah mereka produksi.

Di masa pandemi seperti yang terjadi saat ini. Sebagai alternatif pemecahan masalah tersebut maka diperlukan solusi yang tepat, sehingga permasalahan yang dialami oleh para pelaku ekonomi di desa Gilangharjo. Salah satu cara yang dapat ditempuh adalah dengan membentuk UMKM di sekitar desa Gilangharjo. Pembentukan UMKM ini dilakukan sebagai sarana masyarakat pelaku ekonomi untuk dapat menjual daganganya secara luas, bersama-sama, terarah, dan terstruktur. Hal ini selain sebagai alternatif solusi juga dapat digunakan sebagai sarana pengembangan ekonomi desa. Pada dasarnya hal ini akan menyokong citacita desa, di mana desa sendiri merupakan salah satu pokok kekuatan sosial ekonomi yang perlu mendapatkan bimbingan, dan juga perhatian khusus dari pemerintah, di era revolusi seperti yang terjadi saat ini desa telah berkembang, dalam berbagai komponen sehingga diperlukan adanya perlindungan dan upaya lebih untuk mengembangkan suatu desa (Feiby Vencentia., et al 2017).

Dalam pembentukan UMKM kuliner berbasis kearifan lokal ini, nantinya masyarakat akan mendapatkan berbagai macam pelatihan, seperti pelatihan strategi pemasaran dan pengemasan sehingga masyarakat akan mendapatkan bekal terkait dua komponen penting ini, agar usaha mereka tetap berjalan di masa pandemic seperi yang terjadi saat ini. Masyarakat akan lebih mudah memasarkan daganganya secara bersamaan, masyarakat juga lebih mudah, bekerjasama dengan masyarakat lainnya untuk bersama-sama memasarkan dagangannya dan mencari pelanggan secara dalam jaringan (daring), karena media daring atau online saat ini sangat diunggulkan dalam hal ekonomi, masyarakat daoat memasakan dagangannya secar daring, terlebih di masa pandemi Covid-19 di mana masyarakat sangat dibatasi untuk beraktivitas di luar rumah, peristiwa ini sangat sering kita jumpai, terlebih di masa-masa seperti saat ini.

Layaknya organisasi lainnya, UMKM sebagai organisasi bisnis di Indonesia harus mampu bekerjasama demi terwujudnya cita-cita bangsa. Selain itu, dengan adanya pembentukan UMKM diharapkan mampu memunculkan lapangan kerja baru, karena di masa pandemi seperti yang terjadi saat ini, banyak masyarakat yang kehilangan pekerjaannya. UMKM difungsikan juga sebagai alternatif untuk menanggulangi hal itu. UMKM sangat berperan penting dalam pertumbuhan ekonomi bangsa, karena UMKM menyediakan lapangan kerja baru, memperbesar 
potensi pendapatan pajak bagi Negara, dan mendorong munculnya inovasi-inovasi yang kreatif dan seseuai dengan perkembangan zaman Katua (dalam Kikiy Srirejeki, 2016) Dalam artikel ini akan dibahas, bagaimana strategi pembentukan UMKM sebagai solusi untuk menanggulangi kesulitan ekonomi di masa pandemi. Kegiatan in I merupakan salah satu rangkaian program kerja, mahasiswa program studi Pendidikan Bahasa dan Sastra Indonesia, Fakultas Keguruan dan Ilmu Pendidikan, Universitas Ahmad Dahlan, Yogyakarta. Melalui hibah, Program Holistik Pembinaan dan Pemberdayaan Desa (PHP2D) yang didanai oleh Kementrian Pendidikan dan Kebudayaan Republik Indonesia, tahun 2020. Pembentukan UMKM ini berlangsung mulai dari awal bulan September 2020 hingga akhir Oktober 2020.

\section{METODE PELAKSANAAN KEGIATAN}

Metode pelaksanaan yang dilakukan dalam kegiatan ini adalah sebagai berikut:

Pertama, metode pendataan masyarakat sekaligus sosialisasi kepada masyarakat terkait program. Metode ini dilaksanakan untuk mengetahui seberapa banyak masyarakat yang menjadi pelaku usaha di bidang kuliner kearifan lokal. Selanjutnya dalam tahapan pertama ini dlakukan juga metode sosialisasi kepada masyarakat khusunya pelaku usaha bidang kuliner kearifan lokal di desa Gilangharjo. Kegiatan sosialisasi dilakukan untuk memberikan informasi kepada masyarakat terkait pelaksanaan program, mulai dari awal hingga akhir kegiatan.

Kedua, pelatihan strategi pengemasan dan pemasaran yang didampingi oleh Dinas Koperasi Usaha Kecil Menengah dan Perindustrian Kabupaten Bantul. Dalam metode ini masyarakat diajarkan bagaimana cara melakukan strategi pengemasan agar produk yang mereka buat menarik pembeli di pasaran, masyarakat juga diajrkan mengenai bagaimana cara pemasaran melalui laman digital, baik itu E-commerce, Instagram, YouTube, dan media sosial lainnya. Selaian kegiatan tersebut, dalam metode ini masyarakat juga diberikan pelatihan untuk mengurus izin usaha melalui laman Oss, kegiatan ini dibina langsung oleh mitra dari Dinas Koperasi Usaha Kecil Menengah dan Perindustrian Kabupaten Bantul.

Ketiga, metode pelaksanaan yang dilakukan dalam kegiatan ini adalah pembentukan UMKM. Pembentukan UMKM dilakukan agar para pelaku usaha bidang kuliner lokal di desa Gilangharjo, memiliki struktur yang terorganisasi. Merka dapat bekerjasama dan membentuk sebuah susunan organisasi yang dipimpin oleh seorang ketua layaknya struktur organisasi lainnya. Dalam kegiatan ini, menghasilkan struktur organisasi UMKM yang berisi ketua, sekertaris, bendahara, dan para anggota.

Keempat, metode pelaksanaan terakhir dalam kegiatan ini adalah pemasraan. Kegiatan ini dilakukan untuk memasarkan secara terpusat, bersama dan terorganisasi. Kegiatan pemasaran dipasarkan melalui laman digital, namun dalam kegiatan pemasaran ini masayarakat juga tetap melayani jual beli secara langsung melalui sentra kuliner yang sudah dibentuk. Sentra kuliner tersebut bernama "Sentra Kuliner Gilangharjo" 


\section{HASIL DAN PEMBAHASAN \\ a. Pendataan dan Sosialisasi}

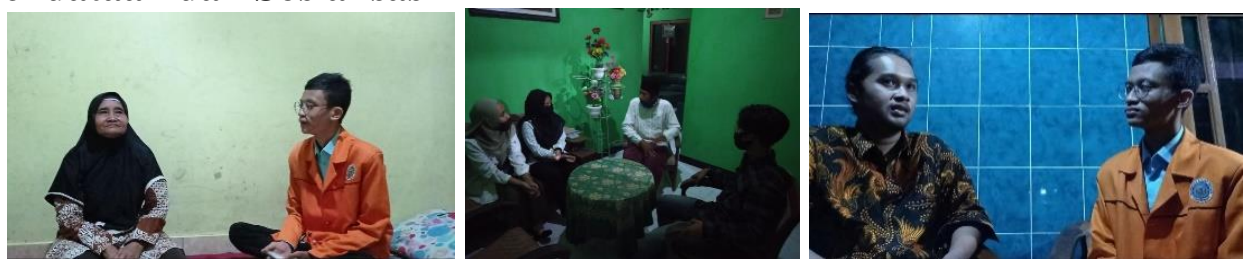

Gambar 1. Pendataan dan Sosialisasi Kegiatan

Kegiatan pendataan dan sosialisasi dilakukan dengan mendatangi rumah masyarakat secara bergantian. Hal ini dilakukan untuk mengetahui secara jelas informasi yang disampaikan kepada masyarakat, selain itu kegiatan ini bertujuan untuk memberikan informasi terkait sosialisasi kepada masyarakat dengan tepat, agar program yang dijalankan sesuai dan tepat sasaran. Dalam kegiatan sosialisasi ini, masyarakat kami berikan informasi terkait berjalannya program, baik itu tempat di mana program akan diadakan, waktu dserta sasaran.

\section{b. Pelatihan Strategi Pengemasan dan Pemasaran}
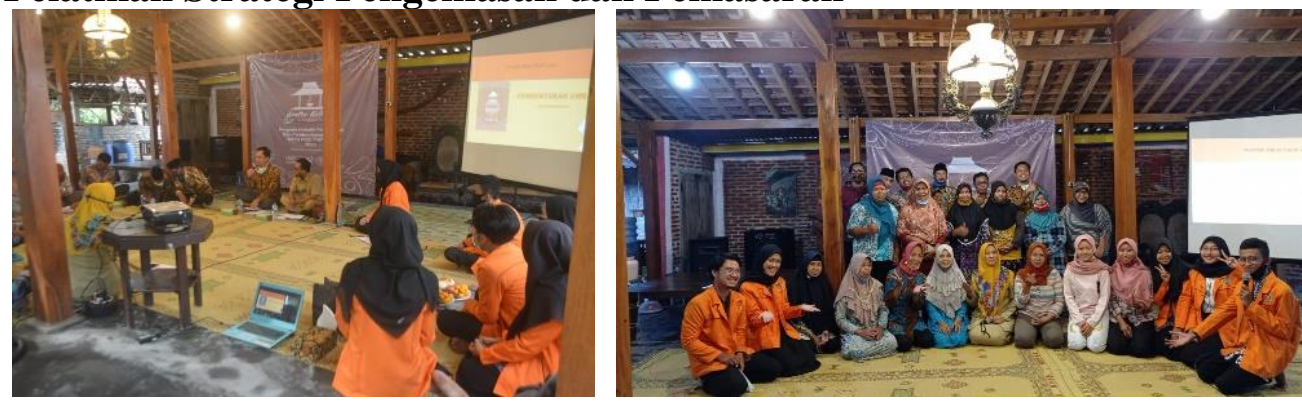

Gambar 2. Pelatihan Strategi Pengemasan dan Pemasaran

Kegiatan ini dilakukan untuk membekali masyarakat dalam hal strategi pengemasan produk yang dijual dan strategi pemasaran melalui laman digital. Dalam kegiatan ini masyarakat dibekali secara langsung oleh perwakilan dari dinas koperasi usaha kecil dan menengah kabupaten Bantul. Dalam kegiatan ini masyarakat juga pelaku usaha juga dibimbing untuk mendaftarkan usah nya dalam laman Oss. Oss sendiri merupakan laman yang digunakan untuk mendaftar dan mengurus perizinan usaha kecil. Kegiatan ini diikuti oleh seluruh pelaku usaha bidang kuliner kearifan lokal yang ada di lingkungan desa Gilangharjo, dan dihadiri oelh kepala RT, kepala Dusun, perwakilan dari kelurahan dan sebagainya. Kegiatan dilakukan di sentra kuliner, di mana sentra ini yang akan digunakan untuk memusatkan dagangan mereka, untuk dijual dan dipasarkan. Dalam kegiatan ini, masayrakat bebas untuk bertanya dan berkonsultasi terkait kesulitan mereka dalam menjalani usaha kepada pihak dinas, sehingga dalam kegiatan ini masyaakat mendapatkan arahan, saran dan bimbingan secara langsung oleh perwakilan dari dinas. 


\section{c. Pembentukan UMKM}

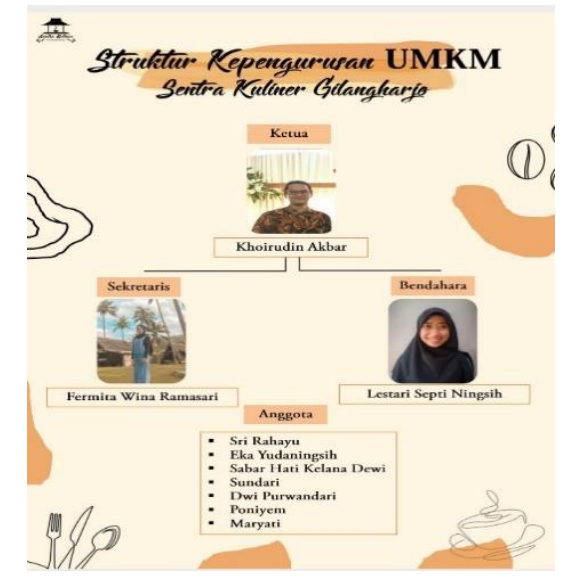

Gambar 3. Struktur Organisasi UMKM

Pembentukan UMKM dilaksanakan dengan cara mengumpulkan masyarakat pelaku usaha kuliner bidang kearifan lokal, dan membentuknya menjadi sebuah organisasi UMKM bidang kuliner kearifan lokal yang dipimpin oleh keua, sekertaris dan bendahara. Pada kegiatan ini dihadiri oleh seluruh pamong desa yang ada di lingkungan desa Gilangharjo. UMKM dibentuk agar masyarakat dapat terorganisasi dalam memasarkan daganganya, sehingga mereka dapat bekerjasama untuk memasarkan dagangannya. Kegiatan ini dilaksanakan di sentra kuliner, di mana sentra kuliner tersebut menjadi induk tempat mereka berjualan, sentra kuliner menjadi pusat mereka dalam menjajakan kuliner berbasis kearifan lokal.

\section{d. Pemasaran}
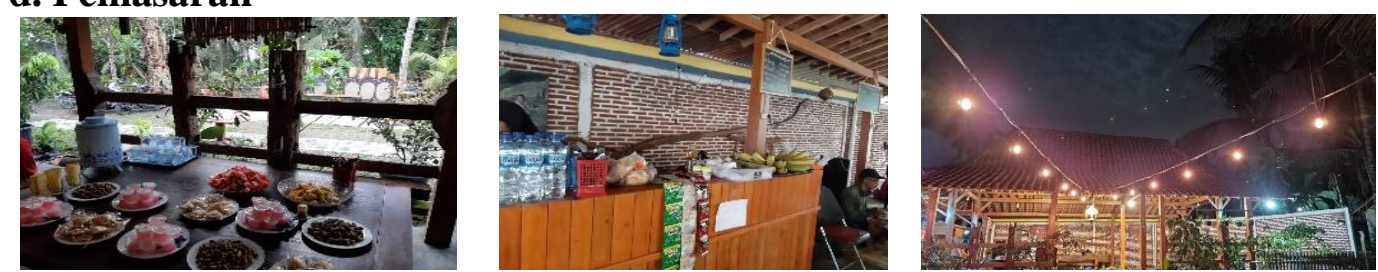

Gambar 4. Pelaksanaan Pemasaran

Dalam kegiatan ini, anggota UMKM menjajakan dagangannya secara bersama. Para anggota UMKM masing-masing menitipkan jajanan yang sudah mereka buat, lalu dijual dan dikelola oleh pengurus UMKM di sentra kuliner. Pelaksanaan pemasaran perdana dilakukan saat visitasi program secara luring oleh TIM dari Kemdikbud. Para anggota UMKM sekaligus mendapatkan kesempatan untyuk berkonsultasi oleh tim reviewer Program Holistik Pembinaan dan Pemberdayaan Desa (PHP2D) Kemdikbud.

\section{KESIMPULAN DAN SARAN}

Berdasarkan rencana kegiatan Pembentukan UMKM melalui program hibah PHP2D Kemdikbud, untuk Himpunan Mahasiswa Program Studi Pendidikan Bahasa dan Sastra Indonesia, FKIP, Universitas Ahmad Dahlan dapat disimpulkan 
sebagai berikut; (1) Kegiatan sosialisasi program berjalan dengan lancar dan sesuai harapan, (2) Kegitaan pelatihan dilaksanakan sesuai harapan dan target yang direncanakan, (3) Kegiatan pemasaran berjalan sesuai rencana, hal ini dibuktikan dengan saat berjalannya program pemasaran, dilakukan juga kegiatan vistasi dan evaluasi oleh TIM reviewer dari kemdikbud. Terima kasih kami ucapkan kepada Kementrian Pendidikan dan Kebudayaan Republik Indonesia, yang telah memberikan kami dan hibah dalam Program Holistik Pembinaan dan Pemberdayaan Desa (PHP2D) tahun 2020, Universitas Ahmad Dahlan terkhusus Biro Kemahasiswaan dan Alumni yang selalu mendukung kegiatan kami, Pemerintah desa Gilangharjo, serta seluruh masyarakat dusun Daleman, desa Gilangharjo, Kecamatan Pandak, Kabupaten Bantul, Provinsi Daerah Istimewa Yogyakarta.

\section{DAFTAR PUSTAKA}

Effendy, A., \& Sunarsi, D. (2020). Persepsi Mahasiswa Terhadap Kemampuan Dalam Mendirikan UMKM Dan Efektivitas Promosi Melalui Online Di Kota Tangerang Selatan. Jurnal Ilmiah MEA (Manajemen, Ekonomi, \& Akuntansi), 4(3), 702-714. https://doi.org/10.31955/mea.vol4.iss3.pp702$\underline{714}$

Feiby Vencentia Tangkhumat, Vicky V.J. Panelewen, Arie D. P. Mirah. (2017). Dampak Program Dana Desa Terhadap Peningkatan Pembangunan Dan Ekonomi Di Kecamatan Pineleng Kabupaten Minahasa. Jurnal AgriSosioEkonomiUnsrat 13 (2A), 335-342.

Haque, MG., Munawaroh, Sunarsi, D., (2020). Analysis of SMEs Culinary Marketing Strategy During Covid 19 Pancemic: A Study at "Sate Bebek Cilegon" Resto in Cilegon, Banten. International Journal of Education, Information Technology, and Others. Vol.3. Issue 2.

Iis Suwartini. (2020). Pelatihan Pendidikan Kesehatan Lingkungan Berbasisi NilaiNilai Keislaman. Jurnal Pemberdayaan: Publikasi Hasil Pengabdian Kepada Masyarakat. ISSN 2580-2569.

Katua, N.T. (2014). The role of SMEs in employement creation and economic growth in selected countries. International Journal of Education and Research 2 (12), 461-472.

Kikiy Srirejeki. (2016). Analisis Manfaat Media Sosial Dalam Pemberdayaan Usaha Mikro Kecil dan Menegah (UMKM). Jurnal Masyarakat Telematika dan Informasi. 7 (1), 57-68.

Sunarsi, D. (2020). The Influence of Supply Chain Strategy on Employee Performance on Small and Medium Business in Beringharjo Market, Yogyakarta- Indonesia. International Journal of Supply Chain Management. Vol. 9, No. 5. 